\title{
Thin-Layer Chromatographic Analysis of Steroids: A Review
}

\author{
SA Bhawani ${ }^{* 1}$, O Sulaiman ${ }^{1}$, R Hashim ${ }^{1}$ and MN Mohamad \\ Ibrahim ${ }^{2}$ \\ ${ }^{1}$ Division of Bio-Resource, Paper and Coatings Technology, School of Industrial Technology, ${ }^{2}$ School of Chemical \\ Sciences, Universiti Sains Malaysia, 11800, Pulau Pinang, Malaysia
}

\begin{abstract}
Thin layer chromatography has been used for the analysis of natural and synthetic steroids in various environmental materials. This review focuses mainly on steroid analysis in environmental materials such as pharmaceuticals, plant products and other biological specimens. The most widely investigated biological specimens are urine and blood plasma or serum. Various chromatographic systems useful for the identification; separation and quantification of surfactants are also reported in this review.
\end{abstract}

Keywords: Steroids; Thin layer chromatography; Environmental materials; Biological specimens 


\section{INTRODUCTION}

Steroids are terpenoid lipids characterized by the sterane or steroid nucleus: a carbon skeleton with four fused rings, generally arranged in a 6-6-6-5 fashion. Steroids vary by the functional groups attached to these rings and the oxidation state of the rings. The specificity of their different biological actions is due to the various groups attached to a common nucleus. When alcohol groups $(\mathrm{OH})$ are attached, steroids should properly be called sterols (e.g., cortisol), whereas ketone groups $(\mathrm{C}=\mathrm{O})$ make them sterones (e.g., aldosterone).

Steroids comprise a large group of substances that mediate a very varied set of biological responses. The most widespread in the body is cholesterol, an essential component of cell membranes and the starting point for the synthesis of other steroids - sex hormones, adrenal cortical hormones, and the bile salts. Steroids (e..g., glucocorticoids, mineralocorticoids, androgens,estrogens and progestagens) have major responsibilities as hormones, controlling metabolism, salt balance, and the development and function of the sexual organs as well as other biological differences between the sexes. Steroids in the form of bile salts (e.g., salts of cholic and deoxycholic acid and their glycine and taurine conjugates) assist in digestive processes, while another steroid is a vitamin (calcitriol) that takes part in calcium control. Steroids (naturally occurring or synthetic) such as methylprednisolone, hydrocortisone, glucocortisteroids, corticosteroids, squalamine, oestrogens, androgens, are also used for the treatment of various diseases such as allergic reactions, arthritis, some malignancies, and diseases resulting from hormone deficiencies or abnormal production. In addition, synthetic steroids (e.g., mifepristone) that mimic the action of progesterone are widely used as oral contraceptive agents. Other synthetic steroids (e.g., oxandrolone) are designed to mimic the stimulation of protein synthesis and muscle-building action of naturally occurring androgens. Steroids, such as nandrolone, dromostanolone, stanozolol, are often used illegally to increase the performance of competitive athletes of almost all age groups. They are banned in most sports competitions such as the Olympic Games.

\section{Classification of Steroids}

Steroids have been classified into a number of groups by Scott [1] based on their functions as follows: (i) sterols and steroid alcohols, usually with double bonds; (ii) sex hormones - steroids produced mainly in the testis (androgens) or ovary (estrogens); (iii) adrenocortical hormones - steroids produced in the cortex of the adrenal gland; (iv) bile acids - steroids usually bonded to taurine or glycine and functioning as emulsionstabilizing agents in the intestine; (v) sapogenins - plant products with a steroid bonded to carbohydrates; (vi) cardiac glycosides - plant products similar to sapogenins and used as heart stimulants; and (vii) vitamin D

\section{ANALYSIS OF STEROIDS}

Many procedures used for the quality control and quality assurance of steroids are based on classical methods of analysis. However, the need for improved precision and accuracy has led to the increased use of instrumental analysis. Thus, the development of fast and reliable analytical methods for quality control, including the identification of synthesis byproducts and purity tests, are both important and challenging. Thin-layer chromatography (TLC) continues to be an important method for qualitative analysis of steroids because of its inherent advantages - many samples can be analyzed simultaneously and quickly, and multiple separation techniques and detection procedures can be applied. This review presents the contribution of thin-layer chromatography in the analysis of steroids from 1990-2009. It addresses most aspects of thin-layer chromatography, including detection, separation and quantification of steroids. 


\section{Thin-layer chromatography of steroids}

Szepesi and Gazdag wrote a book chapter on the TLC of steroids, and it included information on sample preparation as well as stationary-phase and mobile-phase systems useful for the separation of steroidal pharmaceuticals [2]. The authors also provided detailed methods of detection and quantification of steroids, and later on, updated their review to include coverage through 1994 [3]. Dreassi et al [4] have also reviewed the application of TLC to steroids in pharmaceutical analysis while Jain has provided some information on the analysis of steroid hormones in his review on TLC in clinical chemistry [5].
TLC continues to be an important method for the determination of steroids because of its advantages. Many samples can be analyzed simultaneously and quickly at relatively low cost; also, multiple separation techniques and detection procedures can be applied and the detection limits are often in the low nanogram range, and quantitative densitometric methods are accurate. Modern approaches in thin-layer chromatography enable analysts to separate and determine steroids in complex mixtures, including various environmental samples. Steroids and their metabolites are analyzed by thin-layer chromatography in a variety of samples such as biological samples, plants and pharmaceutical formulations. Table 1(a)-(e) shows several thin-layer chromatographic systems designed for the analysis of steroids [6-29].

Table 1(a): Thin-layer chromatographic analysis of steroids

\begin{tabular}{|c|c|c|c|c|}
\hline Analyte & $\begin{array}{l}\text { Stationar } \\
\text { y phase }\end{array}$ & Mobile phase & Remarks & Ref \\
\hline $\begin{array}{l}\text { Cholestrol, } \\
\text { allylestrenol, } \\
\text { pregnanediol, } \\
\text { etc. }\end{array}$ & $\begin{array}{l}\text { RP- } \\
\text { HPTLC } \\
\text { plates }\end{array}$ & $\begin{array}{l}\text { Acetronitrile/methanol, } \\
\text { acetronitrile/water and } \\
\text { methanol/water in different binary } \\
\text { mixtures }\end{array}$ & $\begin{array}{l}\text { Investigation of the retention behavior } \\
\text { of } 12 \text { sreroids.Mixture of } 10 \mathrm{~g} \text { copper } \\
\text { sufate and } 5 \mathrm{~mL} \text { o-phosphoric acid } \\
(86 \%) \text { dissolved in } 95 \mathrm{~mL} \text { methanol. }\end{array}$ & 6 \\
\hline $\begin{array}{l}\text { Androgens } \\
\text { and gestagens }\end{array}$ & Silica & $\begin{array}{l}\text { Cyclohaxane/ethylacetate/ethanol } \\
(24: 16: 1) \text { and } \\
\text { chloroform/benzene/ethanol(36:4:1 } \\
\text { ) in one direction } \\
\text {;chloroform/acetone }(9: 1) \text { and } \\
\text { hexane/dichloromethane/ } \\
\text { acetronitrile }(4: 3: 2) \text { in second } \\
\text { direction for androgens and } \\
\text { gestagens respectively }\end{array}$ & $\begin{array}{l}\text { HPTLC separation of anabolic } \\
\text { Androgens. } \\
\text { Detected by fluorescence after } \\
\text { immersion in a } 5 \% \text { sulfuric acid-ethanol } \\
\text { solution for } 30 \text { sec and viewed under } \\
\text { UV366nm. }\end{array}$ & \\
\hline Steroids & Silica & $\begin{array}{l}\text { Chloroform/ethanol/water } \\
(188: 12: 1)\end{array}$ & $\begin{array}{l}\text { Detection under } \\
\text { UV.Quantification by } \\
\text { radioimmunoassay. }\end{array}$ & 8 \\
\hline $\begin{array}{l}\text { Progesterone, } \\
\text { testosterone, } \\
\text { testosterone } \\
\text { hydrogen } \\
\text { sulfate sodium } \\
\text { salt, etc. }\end{array}$ & Silica & $\begin{array}{l}\text { Methanol/ethylacetate/chloroform/ } \\
\text { methylenechloride (first inverse } \\
\text { gradient program) and } \\
\text { methanol/chloroform (second } \\
\text { inverse gradient program) }\end{array}$ & $\begin{array}{l}\text { Programmed multiple development of } \\
\text { analysis of steroids. } \\
\text { Detected under UV } 254 \text {.Densitometry } \\
\text { was used for the quantification. }\end{array}$ & 9 \\
\hline Oxo-steroids & $\begin{array}{l}\text { Silica gel } \\
\mathrm{F}_{254}\end{array}$ & Chloroform/methanol $(97: 3)$ & $\begin{array}{l}\text { Measurement of } 17 \text {-oxo steroids in biol. } \\
\text { Fluids with TLC and fluorometric } \\
\text { scanning detection. Dansylhydrazine } \\
\text { was used as a prelabeling reagent. } \\
\text { Linearity of fluorescence detection was } \\
\text { obtained at 30-1000 ng. }\end{array}$ & 10 \\
\hline
\end{tabular}


Table 1(b): Thin-layer chromatographic analysis of steroids (contd.)

\begin{tabular}{|c|c|c|c|c|}
\hline Analyte & $\begin{array}{l}\text { Stationary } \\
\text { phase }\end{array}$ & Mobile phase & & Ref \\
\hline $\begin{array}{l}\text { Hydrocortisone, } \\
\text { prednisolone, } \\
\text { mesylate, etc. }\end{array}$ & & $\begin{array}{l}\text { Benzene/ } \\
\text { ethylacetate }(1: 1)\end{array}$ & $\begin{array}{l}\text { Use of colour } \\
\text { photodocumentation of UV- } \\
\text { irradiated thin-layer } \\
\text { chromatograms for the analysis } \\
\text { of steroids.Detected by spraying } \\
\text { with a } 10 \% \text { ethanolic solution of } \\
\text { sulfuric acid followed by heating } \\
\text { at } 100^{\circ} \mathrm{C} \text { for } 2 \text { to } 4 \text { min }\end{array}$ & 11 \\
\hline Anabolic steroids & Silica & $\begin{array}{l}\text { Chloroform/aceto } \\
\text { ne }(9: 1) \text { in one } \\
\text { direction and } \\
\text { cyclohexane/ethy } \\
\text { lacetate/methano } \\
\text { I }(117: 78: 11) \text { in } \\
\text { the opposite } \\
\text { direction }\end{array}$ & $\begin{array}{l}\text { Analysis of anabolic steroids by } \\
\text { high-performance thin-layer } \\
\text { chromatography.Detected by } \\
\text { spraying with } 10 \% \text { sulfuric acid in } \\
\text { methanol and heating for } 10 \text { min at } \\
95^{\circ} \mathrm{C} \text { in day light and under UV } \\
366 \text { nm. Further confirmation was } \\
\text { done by GC-MS }\end{array}$ & 12 \\
\hline $\begin{array}{l}\text { Cortisone, } \\
\text { hydrocortisone, } \\
\text { estradiol, } \\
\text { Estradiol benzoate, } \\
\text { estriol,estrone, } \\
\text { methyltestosterone, } \\
\text { testosterone, } \\
\text { testosterone } \\
\text { propionate, } \\
\text { prednisolone, } \\
\text { pegnandiol and triol, } \\
\text { progeterone and } \\
\text { Reichstein's S }\end{array}$ & $\mathrm{NH}_{2} \mathrm{~F}_{245 \mathrm{~s}}$ & $\begin{array}{l}\text { Chloroform/ethan } \\
\text { ol/formic acid } \\
\text { (50:10:10), } \\
\text { Chloroform/meth } \\
\text { anol }(95: 5) \text {, } \\
\text { Chloroform/1- } \\
\text { propanol/formica } \\
\text { cid (50:10:5) }\end{array}$ & $\begin{array}{l}\text { Analysis and separation of steroids } \\
\text { on } \mathrm{NH}_{2} \text { layers. }\end{array}$ & 13 \\
\hline $\begin{array}{l}\text { Cortisole, cortisone, } \\
\text { testosterone and } \\
\text { progesterone }\end{array}$ & $\mathrm{NH}_{2} \mathrm{~F}_{245 \mathrm{~s}}$ & $\begin{array}{l}\text { Chloroform/ethan } \\
\text { ol }(95: 5)\end{array}$ & $\begin{array}{l}\text { Separation and detection of } \\
\text { steroids. Plates were heated to } \\
\text { approx. } 170^{\circ} \mathrm{C} \text { for } 12 \text { min for } \\
\text { fluorescence development. } \\
\text { Flourescence can be increased two } \\
\text { fold by dipping plates into a } \\
\text { mixture of hexane- paraffin }(2: 1 \mathrm{v} / \mathrm{v})\end{array}$ & 14 \\
\hline Steroids & $\begin{array}{l}\text { Silica } \\
\text { impregnated } \\
\text { with silver } \\
\text { nitrate }\end{array}$ & $\begin{array}{l}\text { 1. Hexane/ethylac } \\
\text { etate }(3: 1,2: 1) ; \\
\text { 2.hexane/ether } \\
(10: 1,5: 1) ; \\
\text { 3.hexane; } \\
\text { 4.hexane/tolune } \\
(10: 1)\end{array}$ & $\begin{array}{l}\text { Silver nitrate impregnated silica } \\
\text { layers were used for the separation } \\
\text { of steroids. }\end{array}$ & 15 \\
\hline $\begin{array}{l}\text { Allylestrenol, } \\
\text { desogestrel, } \\
\text { ethynodiol, etc. }\end{array}$ & Silica gel & $\begin{array}{l}\text { Cyclohexane/but } \\
\text { ylacetate/chlorof } \\
\text { orm (86:7:7); } \\
\text { toluene/ethylacet } \\
\text { ate/chloroform } \\
(5: 1: 4)\end{array}$ & $\begin{array}{l}\text { One- and two- dimensional HPTLC, } \\
\text { TLC and personal OPLC analysis } \\
\text { of steroids. }\end{array}$ & 16 \\
\hline
\end{tabular}


Table 1(c): Thin-layer chromatographic analysis of steroids (contd.)

\begin{tabular}{|c|c|c|c|c|}
\hline Analyte & $\begin{array}{l}\text { Stationary } \\
\text { phase }\end{array}$ & Mobile phase & Remarks & Ref \\
\hline $\begin{array}{l}\text { Chenodeoxycho } \\
\text { lic acid and } \\
\text { deoxycholic acid }\end{array}$ & $\begin{array}{l}\text { Silica gel } \\
\text { RP- } 18 \mathrm{~F}_{254 \mathrm{~S}} \\
\text { and silica } \\
\text { gel } 60 \mathrm{~F}_{254}\end{array}$ & $\begin{array}{l}\text { 1. methanol-0.3\% sodium } \\
\text { phosphate buffer }(\mathrm{pH}, 7.5) \text {. } \\
\text { First development. } \\
(\mathrm{A}, 80: 20, \mathrm{v} / \mathrm{v})(\mathrm{B}, 70: 30, \\
\mathrm{v} / \mathrm{v})(\mathrm{C}, 65: 35, \mathrm{v} / \mathrm{v}) \\
\text { 2. } n \text {-hexane-ethyl acetate- } \\
\text { acetic acid ,First } \\
\text { development }(\mathrm{A}, 72: 18: 10 \text {, } \\
\text { v/v/v) } \\
\text { 3. methanol-0.3\% sodium } \\
\text { phosphate buffer (pH, 7.5) } \\
\text { containing } 5 \mathrm{mM} \mathrm{Me-b}-\mathrm{CD} \\
\text { (A, } 80: 20, \mathrm{v} / \mathrm{v})(\mathrm{B}, 70: 30 \text {, } \\
\text { v/v) }(\mathrm{C}, 65: 35, \mathrm{v} / \mathrm{v}), \text { Second } \\
\text { development } \\
\text { 4.acetic acid-methanol- } \\
\text { water } \\
\text { (A, } 60: 20: 20, \mathrm{v} / \mathrm{v} / \mathrm{v}) \text {. } \\
\text { Second development }\end{array}$ & $\begin{array}{l}\text { Separation of the } \\
\text { unconjugates and conjugates } \\
\text { of } \\
\text { chenodeoxycholic acid and } \\
\text { deoxycholic acid by two- } \\
\text { dimensional reversed-phase } \\
\text { thin-layer chromatography } \\
\text { with methyl } \beta \text {-cyclodextrin. A } \\
\text { high degree of separation of } \\
\text { individual bile acids in each } \\
\text { homologous series was } \\
\text { achieved on a RP-HPTLC } \\
\text { plate by developing with } \\
\text { aqueous methanol in the first } \\
\text { dimension and the same } \\
\text { solvent system containing } \\
\text { Me- } \beta \text {-CD in the second } \\
\text { dimension. }\end{array}$ & 17 \\
\hline Steroids & Silica gel & $\begin{array}{l}\text { n-hexane/ether/acetic acid } \\
(65: 35: 1) \text { and only } n- \\
\text { hexane for the second } \\
\text { development }\end{array}$ & $\begin{array}{l}\text { Evaluation of a new type of } \\
\text { radiodetector designed for } \\
\text { digital autoradiography of } \\
\text { TLC plates for the detection } \\
\text { of steroids. Quantification by } \\
\text { densitometry after dipping for } \\
30 \text { s in } 3 \% \\
\text { sulfuric acid,drying at } 60^{\circ} \mathrm{C} \\
\text { for } 15 \text { min and heating at } \\
160^{\circ} \mathrm{C} \text { for } 15 \text { min. }\end{array}$ & 18 \\
\hline $\begin{array}{l}\text { Double } \\
\text { conjugates of } \\
\text { bile acids }\end{array}$ & $\begin{array}{l}\text { Silica gel } \\
\text { RP-18F } 254 \mathrm{~S} \\
\text { and silica } \\
\text { gel } 60 \mathrm{~F}_{254}\end{array}$ & $\begin{array}{l}\text { Methanol/water/0.5 moL' } \\
{ }^{1} \text { tetra-n-butylammonium } \\
\text { phosphate } \\
\text { (A,90:10:5; B,802:0:5; } \\
\text { C,75:25:5), for first } \\
\text { development and } \\
\text { Methanol/water/0.5 moL' } \\
\text { 'tetra-n-butylammonium } \\
\text { phosphate containing } 5 \mathrm{mM} \\
\text { Me- } \beta-C D(A, 90: 10: 5 ; \\
\text { B,802:0:5; C,75:25:5), for } \\
\text { second development }\end{array}$ & $\begin{array}{l}\text { Separation of a series of a } \\
\text { polar, ionic and hydrophilic } \\
\text { double conjugates of bile } \\
\text { acids amidated at the C-24 } \\
\text { carboxyl group with the } \\
\text { glycine or taurine and } \\
\text { sulfonated or glucosylated at } \\
\text { hydroxyl groups in the } 5 \beta \text { - } \\
\text { steroid nucleus. }\end{array}$ & 19 \\
\hline $\begin{array}{l}\text { B-sitosterol, } \\
\text { stigmasterol, } \\
\text { campesterol, } \\
\text { etc. }\end{array}$ & $\begin{array}{l}\text { Silanized } \\
\text { silica gel }\end{array}$ & Methanol/water (1:1) & $\begin{array}{l}\text { Preparative TLC of steroids } \\
\text { from Harrisonia abyssinica. } \\
\text { Detected under UV. }\end{array}$ & 20 \\
\hline
\end{tabular}


Table 1(d): Thin-layer chromatographic analysis of steroids (contd.)

Analyte
Levonorgestrel, 13ß-ethyl-
17ß-hydroxy-18,19-dinor-
17a-pregn-
4-en-20-yn-3-one

Androsterone, epiandrosterone, testosterone, etc.

Cortisol and cortisone

Levonorgestrel and ethinyloestradiol

Ergosterol, stigmasterol, dihydrocholestrol, 4cholesten-3one, cholecalciferol and cholesterol acetate Sterols

$\begin{array}{ll}\begin{array}{l}\text { Stationary } \\ \text { phase }\end{array} & \begin{array}{l}\text { Mobile } \\ \text { phase }\end{array} \\ \text { Silica gel } & \begin{array}{l}\text { Toluene/2- } \\ \text { propanol } \\ (90: 10)\end{array} \\ 60 F_{254} & \end{array}$

Silica RP$18 \mathrm{~W}$

$\begin{array}{ll}\text { Silica gel } & \text { Phosphate } \\ 60 & \text { buffer }\end{array}$

Silica gel

\section{Hexane- chloroform- methanol} (1.0:3.0:0.25)
Silica gel
Methanol/dich loromethane $(1: 9)$

Silica gel ater(in different compositions)

\section{Remarks}

Determination of levonorgestrel in release media of an in-situ-forming drugdelivery system based on poly ( $D, L$ lactide-co-glycolide) and N-methyl-2-pyrrolidone. Densitometric detection and quantification were performed at $\lambda=250 \mathrm{~nm}$.

Methanol/wat Lipophilicity of selected steroids was determined by RP. acetonitrile/w HPTLC.Lipophilicity values were estimated by computational methods.

Detected by spraying with sulfuric acid/methanol(1:9) and heating at $120^{\circ} \mathrm{C}$ for $15 \mathrm{~min}$.

Thin-layer chromatographic competitive proteinbinding assay for cortisol and cortisone. Specific and rapid detn. of free cortisol and cortisone in human urine. Detected under UV light.

Simultaneous detn. of steroidal hormones levonorgestrel and ethinyloestradiol both in bulk drug and in low-dosage oral contraceptives. Densitometric anal. of the drugs was carried out in the reflectance mode at $225 \mathrm{~nm}$ by using a computer controlled densitometric scanner.

Improved detection of steroids.

Detected by spraying twice with $10 \%$ phosphomolybdic acid in methanol followed by heating

Semiautomated band-wise sample application, and ether/diethyl ether/glacial acetic acid automated visible mode (80:20:1) densitometry was developed for the determination of the steroids. 
Table 1(e): Thin-layer chromatographic analysis of steroids (contd.)

\begin{tabular}{|c|c|c|c|c|}
\hline Analyte & $\begin{array}{l}\text { Stationary } \\
\text { phase }\end{array}$ & Mobile phase & Remarks & Ref \\
\hline $\begin{array}{l}\text { Progesterone, } \\
\text { trenbolone acetate, } \\
\text { melengestrol acetate, } \\
\text { 17- } \beta \text {-estradiol, 19- } \\
\text { nortestosterone, } \\
\text { fluoxymesterone, } \\
\text { norethandrolone, 4- } \\
\text { chloro- } \delta-1-M e \\
\text { testosterone, clostebol } \\
\text { acetate, } 6 \text { - } \beta \text { - } \\
\text { hydroxymethandienon } \\
\text { e and oxymetholone }\end{array}$ & $\begin{array}{l}\text { Silica gel } 60 \\
\mathrm{~F}_{254}\end{array}$ & $\begin{array}{l}\text { Chloroform/aceto } \\
\text { ne }\end{array}$ & $\begin{array}{l}\text { Simultaneous sepn. of } \\
\text { eleven steroid hormones } \\
\text { and synthetic anabolics. The } \\
\text { investigated steroids were } \\
\text { successfully visualized } \\
\text { under UV light ( } 254 \mathrm{~nm} \text { ), and } \\
\text { after spraying with an } \\
\text { ethanolic soln. of p- } \\
\text { toluenesulfonic acid. }\end{array}$ & 27 \\
\hline $\begin{array}{l}\text { Ethinyl estradiol, } \\
\text { norethisterone, } \\
\text { Nandrolone, etc. }\end{array}$ & Silica gel & $\begin{array}{l}\text { Cyclohexanone/e } \\
\text { thylacetate/chloro } \\
\text { form }(1: 1: 1)\end{array}$ & $\begin{array}{l}\text { Optimization and } \\
\text { comparison of the acidic } \\
\text { visualization of steroids } \\
\text { separated by } \\
\text { OPLC.Detected with sulfuric } \\
\text { acid(under UV } 366 \mathrm{~nm} \text { ) at } \\
\text { three different } \\
\text { concentrations, } \\
\text { phosphomolybdic acid (in } \\
\text { white light) and phosphoric } \\
\text { acid (under UV } 366 \mathrm{~nm} \text { ). } \\
\text { Evaluation by } \\
\text { videodensitometry }\end{array}$ & 28 \\
\hline $\begin{array}{l}\text { Estradiol, } \\
\text { hydrocortisone, } \\
\text { testosterone and } \\
\text { cholesterol }\end{array}$ & Diol $F_{254 \mathrm{~s}}$ & Chloroform & 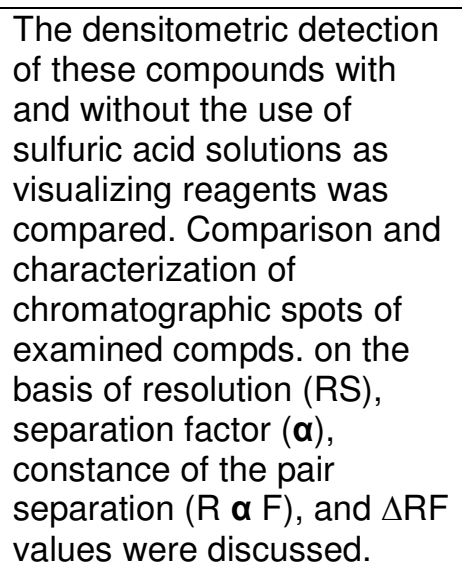 & 29 \\
\hline
\end{tabular}

The 5 androstane isomers were analysed by thin-layer chromatography using optimum mobile phases. The choice of proper mobile phase and the optimization of the mobile phase composition are very important for the analysis of androstane isomers by thin-layer chromatography (TLC). In the 1st step, the proper solvent system was found to be the 
mixture of chloroform, acetone, and petroleum ether chosen from 7 elution systems. In the second step, the composition of the mobile phase was optimized by "simplex" and "prisma" methods. The optimum TLC system can be applied for the separation of androstane isomers from real samples such as drug formulation, biological and natural resources [30]. Separation of a large number of ecdysteroids was investigated with eleven mobile phases and three stationary phases. Only the use of four mobile phases on three stationary phases enabled the separation of all the ecdysteroids from each other in at least one system. The TLC behaviour of ecdysteroids containing different numbers of hydroxyl groups, sidechain variations, and extra double bonds, and of positional isomers and stereoisomers, was reported and interpreted [31].

A comparative study has been performed on the thin-layer chromatographic detection of different corticosteroids. In this study, twelve different mixtures of organic solvents were compared to assess their efficiency as mobile phases for the separation of eighteen glucocorticosteroids along with four different spray reagents. Optical evaluation of the plates revealed that the combination of choice for optimum separation and detection was chloroform-methanol (92:8), or chloroform-acetone (90:10) as mobile phase and a mixture of 2,4-dihydroxybenzaldehyde, sulfuric acid, and acetic acid as spray reagent [32]. Chromatographic study of 36 estradiol and estrone was conducted on silica and RP18 silica with non-aqueous and aqueousorganic mobile phases. The slopes of the linear relationship between RM and the volume fractions of the polar organic components of the binary eluents were also calculated [33].

A simple thin-layer chromatography immunostaining method using monoclonal antibody against solamargine was developed for the determination of solasodine glycosides [34]. In this method, the solasodine glycosides separated by silica gel TLC were transferred to a polyvinylidene difluoride membrane. The membrane was treated with sodium periodate solution and the with bovine serum albumin (BSA), resulting in a solasodine glycoside-BSA conjugate. Individual spots were stained by monoclonal antibody against solamargine. The newly established immunostaining method can be extended to the analysis of the distribution of solasodine glycosides in the plant extract [34]. Folin-Ciocalteu's reagent along with three new solvent systems was used for the study of 9 anabolic steroids prohibited in sports, namely testosterone undecanoate, methyltestosterone, methandienone, testosterone, testosterone propionate, nandrolone phenylpropionate, ethylsterenol, oxygmetholone, and stanozolol [35].

A rapid, selective and precise stability indicating high performance thin layer chromatography method was developed and validated for the estimation of oestradiol (ESD) in bulk and pharmaceutical dosage forms [36]. ESD is widely used in postclimacteric replacement therapy. The developed method employed silica gel $60 \mathrm{~F}_{254}$ as the stationary phase and chloroformacetone-isopropyl alcohol-glacial acetic acid (9:1:0.4:0.1) as mobile phase. The dense and compact spot of the drug occurred at an $R_{f}$ value of $0.40 \pm 0.02$. Spectrodensitometric scanning-integration was performed on a Camag system at a wavelength of $286 \mathrm{~nm}$. The polynomial regression data for the calibration plots exhibited good linear relationship ( $r=0.9947)$ over a concentration range of $1-8 \mu \mathrm{g}$. Recovery studies were also performed at three experimental levels. The recovery data revealed that the relative standard deviation (RSD) for intra-day and inter-day analysis was found to be 1.27 and $1.75 \%$, respectively. The intentional acidic degradation of oestradiol gave two products. In the presence of an acid, protonation of the $17-\beta$-hydroxyl group occurred, followed by the loss of a water molecule. This would further result in elimination of a proton at C- 
16 position leading to the formation of a double bond at C16-17 position (degradation product I). Furthermore this product could undergo a possible rearrangement to give a double bond at C15-16 position (degradation product II). Thus, the two spots corresponding to the degraded components obtained after acidic degradation, can be attributed to these two alkenes (degradation products I and II) with not much significant difference in the $R_{f}$ values $(0.52 \pm 0.01(n=$ $6)$ and $0.58 \pm 0.01(n=6))$. These compounds, being more non-polar in nature, have $R_{f}$ values higher than the pure drug. The products may also undergo racemization in acidic conditions.

The determination of 20-Hydroxyecdysone in Sida rhombifolia L. and dietary supplements was performed by a simple HPTLC method [37]. The developed method employed glass TLC plates coated with silica gel $60 \mathrm{~F}_{254}$ as stationary phase and chloroform:methanol (8:2) as developing solvent system. The developed method was used to quantitate 20hydroxyecdysone in methanol extract of the whole plant material of Sida rhombifolia and was also successfully applied for the quantitative evaluation of dietary supplements. The densitometric evaluation of 20-hydroxyecdysone (20E) was performed at $250 \mathrm{~nm}$ in reflectance/absorbance mode. High performance thin-layer chromatography (HPTLC) fingerprint of six different Sida species with $20 \mathrm{E}$ was obtained and significant amounts of $20 \mathrm{E}$ were seen in $S$. rhombifolia. However, on derivatization with anisaldehyde-sulfuric acid reagent, each of the species exhibited unique identity in fingerprint that can be used in distinguishing them. In all the samples, 20E showed good separation with an $R_{f}$ value of $0.37 \pm 0.01$. The purity of $20 \mathrm{E}$ in sample bands was ascertained by comparison of spectral scans and UV maximum $(250 \mathrm{~nm})$ with the standard. The five-point calibration curve was plotted in the linearity range of $200-1,000$ ng spot $^{-1}$ of $20 \mathrm{E}$. The two dietary supplements were also analyzed using the proposed method. Among the two dietary supplements, DS-1 was claimed to contain $20 \mathrm{E}$ of $100 \%$ pharmaceutical quality with a serving portion of 1 capsule, i.e., $300 \mathrm{mg}$ of $20 \mathrm{E}$ per serving. Dietary supplement, DS-2, in addition to other plant extracts and additives, contained Ajuga turkestanica and Rhaponticum carthamoides root extract standardized to contain $37.5 \mathrm{mg}$ of $20 \mathrm{E}$ per serving with a serving portion of two capsules (18.75 mg/capsule). The analysis showed DS-1 and DS-2 to contain 95.1 and $17.28 \mathrm{mg}$ of $20 \mathrm{E}$ per capsule, respectively.

The quantitative analysis of sterol (24bEthylcholesta-5, 22E,25-triene-3b-ol) in Agnimantha (Clerodendrum phlomidis Linn) was performed on silica gel $60 \mathrm{~F}_{254}$ plates with chloroform-methanol (98.5:1.5) as the mobile phase [38]. The method employed automated bandwise sample application, and automated visible mode densitometry for the determination of $24 \mathrm{~b}$-ethylcholesta-5,22E,25triene-3b-ol (ECTO) in the aerial part of Clerodendrum phlomidis. The effect of extracting solvents was studied with respect to the content of ECTO in $C$. phlomidis. Various extracts, namely, n-hexane, chloroform, ethyl acetate, methanol and ethanol were chromatographed to evaluate extraction efficiency as well as interferences due to co-eluted compounds. All the sample tracks were scanned at 254 and $366 \mathrm{~nm}$ wavelength, in addition to derivatization with anisaldehyde reagent. It is clearly evident that no interfering compound was eluted in the sample tracks to affect the quantitation of the targeted marker, ECTO. Ethylacetate was found to be the most suitable and exhaustive solvent for sample preparation. A precise and accurate quantification was performed in the linear working concentration range of 150 $400 \mathrm{ng} / \mathrm{band}$ with good correlation $\left(\mathrm{r}^{2}=\right.$ 0.996). This method was also validated for peak purities, precision, robustness, limits of detection (LOD) and quantitation (LOQ), etc, as per $\mathrm{ICH}$ guidelines.

The lipophilicity of some dehydroepiandrosterone derivates was evaluated by RP-18 HPTLC chromatography [39]. Lipophilicity is 
one of the inherent properties of chemical compounds, affecting their biological activity. Lipophilicity plays a determinant role in the transport of compounds through a biological system and it may also influence the formation of a complex between a compound and a receptor or a biomacromolecule at the site of action. The chromatographic behavior of DHEA derivates - 17 $\alpha$-substituted-3 $\beta, 17 \beta$ -dihydroxy-16-oximino derivatives of 5androstene was studied on a C-18 bonded phase with two aqueous eluents, acetonewater and dioxane-water. For lipophilicity determination, each experiment was run in triplicate. For subsequent calculations, mean $R_{M}$ values were used and were calculated as in Eq 1

$$
R_{M=} \log \left(1 / R_{f}-1\right)
$$

The calculated $R_{M}$ values, with different concentrations of the organic solvent, were used for the calculation of $R_{M}^{0}$ values. The calculated $R_{M}$ values were

extrapolated to $0 \%$ of organic modifier concentration $\left(R_{M}^{0}\right)$ using Eq 2.

$R_{M}=R_{M}^{0}-S . p p$

where $\phi$ is the volume fraction of the organic solvent in the mobile phase and $S$ is the change in $R_{M}$ caused by unit change of organic modifier concentration in the mobile phase. The $R_{M}^{0}$ (intercept) is an extrapolated value obtained at $\phi b=0 \%$ (modifier) and represents the most applied chromatographic lipophilic parameter. The linear relationship (Eq 2) was obtained over all of the investigated concentration ranges for all the studied substances in acetone-water and dioxane-water mobile phases. The calculated $R_{M}^{0}$ (intercept) values are different for each compound and depend only on chemical structures (i.e., the substituent in the 17aposition). Although the $R_{M}^{0}$ values depend on the type of organic modifier, there was linear correlation among $R_{M}^{0}$ for acetone and as well as for dioxane. The significant correlation between the $R_{M}^{0}$ values and $S$-slopes indicate that investigated compounds could be considered as a homologous series. Finally, $R_{M}^{0}$ values proved to be a reliable alternative for lipophilicity expression as well as activity, and can be used for further studies of the compounds' quantitative structure-activity relationships.

Steroids in biological samples (urine, etc.) are also determined by thin-layer chromatography. In one attempt [40], cortisol in urine samples of guinea pig was determined by HPTLC, HPLC and TLC-RIA, respectively, and the results obtained by the three methods were compared. HPTLC and TLC-RIA was performed on $\mathrm{NH}_{2} \mathrm{~F}_{254}$ and silica gel $60 \quad F_{254}$, respectively, with the solvent system consisting of chloroform/methanol/water (90:6:0.5). In the case of HPLC, $\mathrm{C}_{18}$-reversed phase was used with water/methanol $(1: 1)$ as the mobile phase. Following intramuscular administration of $25 \mathrm{mg}$ cortisol, cortisol excretion increased from about $10-30 \mu \mathrm{g} /$ day to $400-500 \mu \mathrm{g} /$ day (i.e., HPTLC: $531 \mu \mathrm{g} /$ day; HPLC: $493 \mu \mathrm{g} / \mathrm{day} ;$ and TLC-RIA: 394 $\mu \mathrm{g} /$ day). Similarly, treatment of animals with 20 IU adrenocorticotropic hormone (ACTH) resulted in augmented cortisol excretion, with mean values of 294 (HPTLC), 256 (HPLC) and $143 \mu \mathrm{g} /$ day (TLC-RIA), respectively. The cortisol amounts measured by the HPTLC and HPLC agreed, but the amounts measured by the TLC-RIA were significantly lower.

On the other hand, a simple, inexpensive and reliable method was developed for the determination of cortisol in plasma and urine of guinea pig by thin-layer chromatography and fluorescence derivatization with isonicoitinic acid hydrazine [41]. The developed method employed silica gel 60 $\mathrm{F}_{254}$ as stationary phase and chloroform/methanol $(9: 1, \mathrm{v} / \mathrm{v})$ as mobile phase. After development, the plates were dipped into isonicoitinic acid hydrazine (INH) reagent $(3 \mathrm{~g} \mathrm{INH}, 5 \mathrm{~g}$ trichloroacetic acid, and $300 \mathrm{~mL})$. The fluorescence of the cortisol hydrazone was further increased by dipping the plates into chloroform-liquid paraffin (9:1). 
The fluorescence was measured densitometrically (excitation 366nm; cut-off filter: $>460 \mathrm{~nm})$. The fluorescence intensity was linearly dependent on the amount of cortisol between 1ng - 200ng. The coefficients of variation ranged between 6.3 (1ng) and $1.4 \%$ (200 ng). The sensitivity of this method (< $1 \mathrm{ng})$ enables the measurement of cortisol in the plasma and urine of saline-, ACTH- or cortisol-treated guinea-pigs. Thin-layer chromatography and fluorescence derivatization with isonicoitinic acid hydrazine was also used for the determination of cortisol and cortisone in human morning and overnight urine [42]. Free cortisol and cortisone were also measured by thin-layer chromatographic competitive protein-binding assay in the urine of male individuals who abstained from water intake for $2 \mathrm{~h}$ or who ingested $1 \mathrm{~L}$ of water [23]. In this study, silica gel $60 \mathrm{~F}_{254}$ plates and acetone-toluene (1:1) were used for the chromatography. Chicken serum was used as the source of corticosteroid binding globulin, because it binds cortisol and cortisone with a similar high affinity.

\section{CONCLUSION}

Thin layer chromatography (TLC) is a globally accepted practical solution to characterize raw herbs, active constituent-enriched extracts and their formulations. Standardized TLC procedures can be used effectively for screening analysis as well as quality evaluation of a plant or its derived herbal products. Owing to the simplicity and efficiency of TLC, specific and rapid determination of various steroids in humans and various other animals can be carried out. The procedure can be employed for the routine analysis of steroids in pharmaceutical formulations and in bulk drug preparations as well as for the quality assurance of related extracts and market samples. Interest in TLC has increased with improvements in TLC instrumentation and methods, and especially in the last few years, with the development of new MS methods for detection. If standard compounds are not available, identification of unknowns has to be done with more specific techniques, such as infra-red spectroscopy and MS detection.

\section{ACKNOWLEDGEMENT}

The first-named author is grateful to Universiti Sains Malaysia, Malaysia for providing postdoctoral fellowship.

\section{REFERENCES}

1.Scott RM .Clinical Analysis by Thin-Layer Chromatography Techniques. Ann ArborHumphrey Science Publishers, Ann Arbor, MI. 1969.

2. Szepesi G, Gazdag M. Steroids. In Handbook of Thin Layer Chromatography,Sherma J, Fried B (Eds.) Marcel Dekker, New York, 1991, p. 907.

3. Szepesi G, Gazdag M. Steroids. In Handbook of ThinLayer Chromatography. Sherma J, Fried B (Eds.) Marcel Dekker, New York, 1996, p. 971.

4. Dreassi E, Ceramelli G, Corti P. Thin-layer chromatography in pharmaceutical analysis. In Practical Thin-Layer Chromatography-A Multidisciplinary Approach. Fried B., Sherma J. (Eds.) CRC Press, Boca Raton, FL, 1996, p. 231.

5. Jain $R$. Thin-layer chromatography in clinical chemistry. In Practical Thin-Layer Chromatography-A Multidisciplinary Approach. Fried B., Sherma J. (Eds.). CRC Press, Bxoca, Raton, FL, 1996, p. 131.

6. Lamparczyk H, Ochocka RJ, Zarzycki P, Zielinski JP. Separation of steroids by reversed-phase HPTLC using various binary mobile phases. J. Planar Chromatogr., 1990; 3: 34-37.

7. De Brabander HF, Van Hoof J. HPTLC analysis of residues of anabolics in meat and kidney fat. J. Planar Chromatogr., 1990; 3: 236-242.

8. Feuske M, Schonbeiter H. Thin-layer chromatography on silica coated aluminium sheet as an adjunct to radioimmunoassay of steroids. $\mathrm{J}$. Chromatogr., 1991; 563: 178- 183.

9. Matyska M, Siouffi AM, Soczewinski E. Programmed multiple development (PMD) analysis of steroids by planar chromatography with a new modification of the

horizontal sandwich chamber. J. Planar Chromatogr., 1991; 4: 255-257.

10. Zdena T. Thin-layer chromatography of urinary 17oxosteroids using

dansylhydrazine as a prelabeling reagent. J. Chromatogr. Biomed. Appl., 1991; 570: 396398.

11. Vegh Z. True color photodocumentation of UVirradiated thin layer chromatograms.

J. Planar Chromatogr., 1993; 6: 341-345. 
12. Daeseleire E, Vanoosthuyze K, Van Peteghem C. Application of high-performance thin-layer chromatography and gas chromatographymass spectrometry to the detection of new anabolic steroids used as growth promotors in cattle fattening. J. Chromatogr., 1994; 674: 247-353.

13. Klaus R, Fischer W, Hauck HE. Analysis and chromatographic separation of some steroid hormones on $\mathrm{NH}_{2}$ layers. Chromatographia, 1994; 39: 97-102.

14. Fenske M. Improved detection of steroids on $\mathrm{NH}_{2}$ layers. Chromatographia, 1995; 41: 175-177.

15. $\mathrm{Li} T$, Li J, Li H. Modified and convenient preparation of silica impregnated with silver nitrate and its application to the separation of steroids and terpenoids. J.Chromatogr. A, 1995; 715: 372375.

16. Ferenczi-Fodor K, Lauko A, Wiskidenszky A, Vegh Z, Jszaszy K. Chromatographic and spectroscopic investigation of irreversible adsorption in conventional TLC and HPTLC and in OPLC. J. Planar Chromatogr., 1999; 12: 30-37.

17. Momosea T, Murea M, lidab T, Gotoc J, Nambara T. Method for the separation of the unconjugates and conjugates of chenodeoxycholic acid and deoxycholic acid by two- dimensional reversed-phase thin-layer chromatography with methyl $\beta$-cyclodextrin. J. Chromatogr. A, 1998; 811: 171-180.

18. Vingler P, Gerst $C$, Boyera N, Galey I, Christelle $C$, Bernard BA, Dzido T, Tardieu F, Hennion C, Filthuth $H$, Charpak $G$. Low-level radioquantitation of lipids and steroids in the pilosebaceous gland-a journey to the limit of a sparking chamber. J. Planar Chromatogr., 1999; 12: 244-254.

19. Sasaki T, Wakabayashi M, Yamaguchi T, Kasuga $Y$, Nagatsuma M, Lida T, Nambara

T. Separation of double congugates of bile acids by two-dimensional high performance thin-layer chromatography with tetra-n-butylammonium phosphate and methyl $\beta$-cyclodextrin. Chromatographia, 1999; 49: 681-685.

20. Balde AM, Apers S, De Bruyne TE, Van Den Heuvel $H$, Claeys $M$, Vlietinck $A J$, Pieters $L A C$. Steroids from Harrison abyssinica. Planta Med., 2000; 66: 67-69.

21. Khakpour M, Jamshidi A, Entezami AA, Mirzadeh $H$. HPTLC procedure for

determination of levonorgestrel in the drug-release media of an in-situ-forming

delivery system. J. Planar Chromatogr.,2005; 18: 326-329.

22. Pyka A, Babuska M. Lipophilicity of Selected Steroid Compounds. I. Investigations on RP18W Stationary Phase by RP-HPTLC. J. Liq. Chromatogr. Rel. Technol., 2006; 29: 18911903.

23. Fenske M. Thin-layer chromatographic competitive protein-binding assay for cortisol and cortisone, and its application to urine samples from healthy men undergoing water diuresis. Chromatographia , 2006; 63: 383-388.

24. Reza FA, Rajabi KA, Mojtaba S. Stability-indicating high-performance chromatographic determination of levonorgestrel and ethinyloestradiol in bulk drug and in low-dosage oral contraceptives. Anal. Chim. Acta, 2006; 572: 237-242.

25. Zarzycki PK, Baran M, Wlodarczyk E, Bartoszuk MA. Improved detection of ergosterol ,stigmasterol and selected steroids on silica coated TLC plates using phosphomolybdic acid staining. J. Liq. Chromatogr. Relat. Technol., 2007; 30: 2629- 2634.

26. Tamara H, Joseph S. Determination of Sterols and Fatty Acids in Prostate Health Dietary Supplements by Silica Gel High Performance Thin Layer Chromatography with Visible Mode Densitometry. J. Liq. Chromatogr. Rel. Technol., 2007; 30: 2329- 2335.

27. Meliha L, Fehim K, Miroslav S, Aleksandra M. Planar chromatography of steroid hormones and anabolics. Acta Chimica Slovenica, 2007; 54: 88-91.

28. Bagocsi B, Vegh Z, Ferenczi-Fodor K.Otimization of the visualization of steroids separated by OPLC. J. Planar Chromatogr., 2008; 21: 107112.

29. Pyka A. Spectrodensitometry application to analytical identification of estradiol, hydrocortisone, testosterone and cholesterol on Diol plates. J. Liq. Chromatogr. Rel. Technol., 2009; 32: 1084-1095.

30. Claudia C, Anamaria H, Sorin H. Analysis of some steroids by thin-layer chromatography using optimum mobile phases. J. Pharm. and Biomed. Anal., 2006; 41: 633-637.

31. Báthori M, Hunyadi A, Janicsák G, Máthé I. TLC of ecdysteroids with four mobile phases and three stationary phases. J. Planar Chromatogr.,2004; 17: 335-341

32. Olga $H$, Thea R, Jose Juan S. Comparative study of the thin-layer chromatographic detection of different corticosteroids. J. Planar Chromatogr., 1998; 11: 305-308.

33. Petrovic SM, Acanski M, Pejanovic VM, Petrovic JA. Retention behaviour of esteradiol and estrone derivatives in normal and reversed phase thin layer chromatography. J. Planar Chromatogr., 1993; 6: 29-33.

34. Hiroyuki T, Waraporn P, Chiyumi T, Yukihiro S. A simple determination of steroidal alkaloid glycosides by thin-layer chromatography immunostaining using monoclonal antibody against solamargine. FEBS Letters, 1997; 404: 279-282.

35. Sharma JD, Sharma AK. Thin layer chromatographic study of some anabolic sport steroids. Indian Journ. Forensic Sci., 1991; 5: 117-122.

36. Kotiyan PN, Vavia PR. Stability indicating HPTLC method for the estimation of estradiol .J. Pharm. Biomed. Anal. 2000; 22: 667-671. 


\section{Bhawaniet al}

37. Jadhav AN, Rumalla CS, Avula B, Khan IA. HPTLC method for determination of 20Hydroxyecdysone in sida rhombifolia L. and dietry supplements. Chromatographia, 2007; 66: 797-800.

38. Shanker K, Singh SC, Pant S, Srivastava $P$, Yadav $A K$, Pandey $R$, Verma RK, Gupta MM. Quantitative TLC analysis of sterol (24 $\beta$ ethylcholesta-5, 22E,25-triene-3 $\beta$-ol) in Agnimantha(Clerodendrum phlomidis linn) Chromatographia ,2008; 67: 269-274.

39. Perisic-Janjic N, Djakovic-Sekulic T, Stojanovic S, Penov-Gasi K. Evaluation of the liphophilicity of some dehydroepiandrosterone derivatives using RP-18 HPTLC chromatography. Chromatographia, 2004; 60: S201-S205.
40. Fenske M. Determination of cortisol in guinea pig urine by high-performance thin-layer chromatography ,high-performance liquid chromatography, and thin-layer chromatography/radioimmunoassay. Chromatographia, 1997; 44: 50-54.

41. Fenske M. Determination of cortisol in plasma and urine by thin-layer chromatography and fluorescence derivatization with isonicotinic acid hydrazide.Chromatographia, 1998; 47: 695-700.

42. Fenske M. Determination of cortisol and cortisone in human morning and over night urine by thinlayer chromatography and and fluorescence derivatization with isonicotinic acid hydrazide. Chromatographia, 2000; 5 